\title{
The Place of "Culture" in the College English Classroom
}

\author{
Qing Xu \\ College of Foreign Languages \\ Qingdao University of Science \& Technology \\ 69 Songling Road, Qingdao 266061, China \\ Tel: 86-532-8895-6018 E-mail: allyxq@sina.com
}

The paper is part of the research findings of the 2006 key Social Science project establishment "Research of College English STSR Teaching Strategies" of Qingdao University of Science \& Technology.

\begin{abstract}
In response to the contrast between the instructional focus of the classroom practice and the actual communicative requirements of campus setting, this paper points out the constructive suggestions for the cultivation of culture awareness in college English education.
\end{abstract}

Keywords: Cultural awareness, Cultural instruction

\section{Introduction}

In the field of foreign language teaching, one aspect that occasionally emerges as a topic of discussion is the relationship between knowledge of a foreign language, and knowledge of the culture from which that language "originated". From my experience with college English education, it would appear that the question of "culture" is often relegated to the end of a language teaching plan. It seems as if it is always something of a bonus if the teacher manages to find time to introduce a bit of the culture of the foreign language into the classroom - some music perhaps, or a typical idiom, in the final lesson of the course. Hence, we may want to ask "how much of the culture of a country should be taught along with the language?"

\section{Statement of the problem}

Acquiring the ability to handle English is very important, which equals to make the efforts to understand the lectures, for a successful academic life at the university. Students have to have communicative competence in English. In other words, what the students are expected to have would be the following skills: listening to lectures, reading textbooks, writing papers, participating in class discussions, etc. These are all indispensable to survive in the university. In the meantime, we know language and culture are inextricably linked. When a person decides to learn English, he or she is not merely absorbing the linguistics of the language, but everything to do with English and English-speaking countries. To speak a language well, one has to be able to think in that language, and thought is extremely powerful, even if the learners themselves are not initially aware of the cultural associations attached to the language they are learning, others will perceive them as being aligned with that culture. However, the students' socio-cultural competence is much weaker than their language competence. After seven years of formal English education, they are still deficient in the ability to actually use English and to understand its appropriate use in normal intercultural communications.

The students' motivation and ability to learn English in the college are influenced by their degree of involvement in the English language and culture. Gardner and Lambert (1972) postulated that learners may have two basic kinds of motivation. The first is integrative motivation, which refers to the desire of language learners to acquire the language while immersing themselves into the whole culture of the language, in order to "identify themselves with and become part of that society" (Brown 1994: 154). The second is instrumental motivation, which refers to the functional need for learners to acquire the language in order to serve some utilitarian purpose, such as securing a job, or a place at a university. The argument is that such instrumentally motivated learners are neither concerned with the culture from which their target language emerged, nor interested in developing any feelings of affinity with the native speakers of that language. However, the traditional attitude among engineering departments of universities has been that language skills are not as crucial for engineers compared to numeric and technical skill. Actually, the lack of interpersonal skills and writing skills were ranked first and second respectively. The fact that there is a gap between the English courses conducted in academic environments and the actual communication tasks required in the real world of work is nothing 
new. Nevertheless, in an attempt to narrow the gap, it has been suggested that university English teachers pay more attention to the spoken and writing process, and focus on the broader social and cultural contexts.

\section{Some tentative suggestions for college English teachers}

\subsection{Introduction}

The goal of foreign language instruction is to help the learners to develop a competence to use the foreign language for communication with people of different cultural backgrounds. Consequently, "Intercultural Communicative Competence" (ICC) ought to be established as the ultimate goal of college English teaching. It conforms most perfectly to the nature of language, language teaching, and foreign language teaching. ICC as the ultimate goal of FLT is supported by sociolinguistics, cultural linguistics, and the theory of intercultural communication. Besides, teaching methodology, course design, and teaching materials should also be adapted to cater to the accomplishment of the ultimate goal.

\subsection{The teaching objective}

Let's take a quick glimpse of the pertinent descriptions and statements in the College English Syllabus (For Non-English Majors, Revised Edition):

"The teaching objective of college English is to help students develop a relatively strong reading ability and general skills of listening, speaking, writing and translating, and by so doing make students able to use English for communications. College English is intended to help students lay a solid foundation of language skills, acquire good language learning strategies, nourish their liberal accomplishment, and adapt themselves to the requirements of social development and economic construction."

But unfortunately, the current English syllabus does not provide a clear statement or description of the ultimate goal of ICC. Logically, in the college English syllabus, there ought to be more space for description and guidelines about cultural instruction in a comparatively systematic pattern in order for the goal of TEFL to have a chance to work.

\subsection{Teachers}

First of all, college English teachers should have strong cultural awareness and pay attention to the cultivation of ICC throughout the whole teaching process. On one hand, they should guide the students to be aware of the customs, value system, behavioral patterns and communicative habits, etc. of the target nation when reading English textbooks, magazines and newspapers, which are the most vivid and wealthy materials for the understanding of a particular culture.

On the other hand, during the teaching of linguistic knowledge and the training of language skills, focus should be laid not only on the correctness of pronunciation, intonation and grammatical rules, but also on the context in which language is used. For example, while teaching writing and speaking, teachers should tell students to speak or write properly according to different occasions, times and social roles. Furthermore, teachers should pay attention to the teaching of non-verbal behaviors of the target culture in order to help the students know its different way of expressing.

\subsection{Curriculum design}

The goal of the fundamental stage is to teach basic knowledge of English, to have students strictly trained in all-rounded fundamental language skills, and to foster students' ability to use the language for real situations, good study style and correct learning methods, and to lay a solid foundation for their studies at the advanced stage. The goal of the advanced stage is to continue the basic skills training, equip students with specialized knowledge and specialty-related knowledge, to further broaden their knowledge scope, to enhance their awareness of cultural differences, and to better their comprehensive use of English for communications. Therefore, the integration of the three strands (English knowledge, skills training and cultural instruction, Liu, 2000) is of vital importance in TEFL:

\subsubsection{To change teaching methods, break away from outdated traditional teaching methods.}

Language teaching should be interrelated with culture teaching, language competence and cultural competence. So from the perspective of a FL learner, to master a foreign language is also to master a new communicative tool, to learn and understand its culture while from the perspective of a FL teacher, to teach a foreign language is also to teach its culture at the same time. If we don't master the cultural background, cultural modes and principles of that foreign language, we are unlikely to teach well that language, as culture is a very important part of language.

\subsubsection{To strengthen the cultural awareness of both teachers and learners.}

As teaching a language actually means to teach its culture at the same time, here I mean the cultural awareness of both source/native language and target language. It's a progress now in China to bring about favor in teaching target language culture in this language teaching, but in the meantime we also realize the lack to culture knowledge of our own Chinese. Some language experts concerned ever did investigations to find out that students really knew little about Chinese culture. Therefore, when we are teaching a target language we can hardly avoid comparing its culture with our 
own. Only in the course of comparison can we grasp their specific features and effectively convey all these to our students.

3.4.3 To select suitable teaching materials.

Language teaching, and particularly language teaching materials, should be directed toward improving intercultural communicative competence. As for teaching materials, they should adopt a common-sense and pragmatic approach, offer a rich array of interesting and highly motivating language-learning resource material and design activities which can raise cultural awareness. That is to say, when we select teaching materials we should know what cultural factors must be directed into our language teaching and what can possibly be omitted. We should select some up-to-date, original English materials with the British or American national flavors so that English teachers can easily develop their multilateral class activities, with cultural background combined with cultural contents. In the meantime materials must be of great interest to readers apart from nice contents. To be interesting or not is an important factor for the teaching materials. It's true for both teachers and students. It's really hard for language teachers to enliven the atmosphere of their classes when the actual teaching materials are boring or too serious while students just listen with a bored expression all the two hours. The textbook Family Album, USA is a practical teaching material, which brings learners to an American family to learn how to communicate with Americans. By introducing the daily life of the Stewarts family - a typical American middle class family, the book vividly shows American communicative culture, which is different from that of China.

\section{Conclusion}

To sum up, in college English classroom, the primary aim is to involve students in an active a way and help them to take on the role of a mediator of cultural knowledge and skills in the language classroom. Specifically, we should first foster students' proper motivation, arouse their cultural awareness, clear away anxiety and cultural stereotypes and at the same time help students to appreciate their native culture.

\section{References}

Agar, M. (1994). Language shock: Understanding the culture of conversation. New York: William Morrow.

Brooks, N. (1968). Teaching culture in the foreign language classroom. Foreign Language Annals, 1, 204-217.

Liddicoat A. J. \& Crozet C. (2000) (Eds) Teaching Languages, Teaching Cultures. Language Australia, Melbourne.

Paribakht, T. (1985) "Strategic competence and language proficiency.” Applied Linguistics. Vol. 6, No.2, pp. 132-146.

Tomalin, B. \& Stempleski, S. (1993). Cultural Awareness. Oxford: Oxford University Press.

Ulichny, M. (1997). The mismanagement of misunderstandings in cross-cultural interactions. Journal of Pragmatics, 27: 233-246. 